\title{
Verb Second in Old Venetian
}

\author{
Onkar Singh \\ University of Cambridge \\ os345@cam.ac.uk
}

Received: 29-01-21

Accepted: 01-03-21

Published: 22-06-21

How to cite: Singh, Onkar. 2021. Verb Second in Old Venetian. Isogloss. Open Journal of Romance Linguistics 7, 7:1-28.

DOI: https://doi.org/10.5565/rev/isogloss.110

\begin{abstract}
This study aims to add to a rich scholarship on the presence of a verb second constraint in old (Italo-)Romance that has been argued to cause V-to-C raising of both the finite verb and one or more constituents, provided we understand this constraint to be lax in these varieties (cf. Ledgeway 2007, 2008). In particular, it analyses a late $14^{\text {th }}$ century old Venetian text, corroborating the existence of this constraint within the variety. Within this study, it will be shown that the syntax of $14^{\text {th }}$ century Venetian is one in which we find the gradual loss of the V2 constraint. This will be shown through a range of phenomena present within the text, such as a loss of Informational Focus fronting, the weakening of subject pronouns, and the loss of scrambling to vP. All in all, this study aims to shed light on the syntax of $14^{\text {th }}$ century Venetian specifically, adding to a growing scholarship on what the incipient loss of the V2 constraint looks like within respective old Romance varieties.
\end{abstract}

Keywords: V2; verb second; old Romance; old Venetian; V-to-C; V-to-T 


\section{Table of Contents}

\section{Introduction \\ 2. Diagnostics for V2 in medieval Romance}

3. V2 in Old Venetian 4. Conclusion

\section{Introduction*}

It has been long argued (see among others Vanelli 1986, 1998; Adams 1987; Fontana 1993, 1997; Roberts 1993; Benincà 1995, 2006; Ribeiro 1995; Vance 1997; Ledgeway 2007, 2008, 2021; Poletto 2014; Wolfe 2018 ${ }^{1}$ ), that medieval Romance varieties ${ }^{2}$ were characterised by a so-called verb second (or V2) constraint, entailing the obligatory raising of the finite verb in matrix clauses to an unfilled $\mathrm{C}$ position. ${ }^{3}$ Across medieval Romance, this is often accompanied by the raising of one or more salient constituents to a higher position within the $\mathrm{CP}$ to that of the finite verb, as in (1a). Subsequently, as we observe in (1b), the presence of the overt complementiser in embedded clauses has been argued to block V-to-C verbal and constituent raising. The V2 hypothesis has been proposed for old Venetian (Benincà 1983; Wolfe 2018) whereby data from a 44page late- $14^{\text {th }}$ century text, Navigatio Sancti Brendani (The Voyage of Saint Brendan), corroborates the presence of this constraint, as exemplified in (1a)-(b), below:

(1) a. [CP [Spec l'ofizio [C' comenza [IP/VP ${ }^{4}$ l'abado tcomenzava t'ofizio tute fiade]]]] the $=$ job started. 3 the $=$ abbot every time

'The abbot started the service every time' $\quad(\mathrm{NSB}, 14)^{5}$

Firstly, I would like to thank both Luigi Andriani and Adam Ledgeway for their joint support and guidance in what was my first attempt at tackling medieval Romance. Additionally, I thank Sam Wolfe for inviting me to present my findings at a conference at Oxford University and for his support regarding my interest in the V2 phenomenon. I am grateful to the audiences of the ARC Linguistics Seminars (January 2019) and Venetian in a Comparative Romance Context workshop (April 2019) where earlier versions of this work were presented. Any mistakes henceforth are my sole responsibility.

For a V2 analysis of old Romanian, see Nicolae (2015, 2019).

The term old Romance is here taken to mean the respective varieties of old Romance, or as Sitaridou (2012:554) defines it, 'an umbrella term for languages that have a common ancestor and not in the sense that the diverse old Romance varieties shared a single grammar'.

3 In this paper, the $\mathrm{CP}$ is assumed to comprise a variety of finer-grained projections à la Rizzi (1997). I assume the CP to be split in the following way, namely in which the Frame projection is higher than the Force projection and no Topic position is available between Focus and Fin, following Benincà and Poletto (2004) and Ledgeway (2010):

\section{[Frame [Force [Topic [Focus [Fin ] ] ]]]}

See fn.8, below, regarding possible parametric variation regarding whether the subject remains in VP or itself rises to a clause-internal position. 
b. Ben so [CP ch' [TP/VP io ho pecado]]
ben know.1SG that =I have.1SG sinned

$(\mathrm{NSB}, 6)$

'I know full well that I have sinned'

The debated presence of this constraint in Old Romance has often led to parallels with the modern Germanic languages (bar modern English) in which this constraint is productive and requires that the finite verb occupy the second clausal position within matrix declarative clauses (c.f. Den Besten 1977; Vikner 1994; Holmberg 2015; and others). Note the parallels between (1a) and (2a-b), below, whereby the preverbal position is evidently not a privileged subject position in these varieties and whereby constituent and verb movement to $\mathrm{C}$ have left the subject in a postverbal position:

(2) a. Heute habe ich gegessen

today have.1SG I eaten

'I have eaten today'

b. Huggomar har jag ärligt talat aldrig sett $i$ den här skogen adders have I honestly speaking never seen in the here forest 'Honestly speaking, I have never seen adders in this forest'

(Swedish, Holmberg 2015:342)

Nonetheless, the arguably problematic use of modern Germanic as the 'prototype' for V2 languages has led a minority in the field (among whom note Kaiser 2002; Martins 2002; Fiéis 2003; Rinke 2007; Rinke and Sitaridou 2004; Sitaridou 2011, 2012; et al.) to argue against the hypothesis, due to the varying attestations of $\mathrm{V} 1$ and $\mathrm{V} 3 *$ orders that we find in the old Romance corpora ${ }^{6}$. In brief, they argue that the V2 hypothesis cannot be sustained for old Romance, whereby these V1 and V3* word orders are divergent when compared with the Germanic model in which they are largely ungrammatical. Sitaridou (2011), for example, argues that what we see is instead a case of stylistic fronting in OR. Meanwhile, others (see Benincà 1983; Ledgeway 2007, 2008; Wolfe 2018; et al.) argue that there is a distinction to be made between the more rigid V2 constraint displayed by continental Germanic and the broad, or lax, V2 constraint that we find in old Romance. In the latter, with both diachronic and diatopic variation within old Romance, it generally holds that the preverbal field allowed the fronting of more than one constituent.

Given the rich level of debate and controversy regarding this constraint in old Romance, in what follows, it will be shown that later old Venetian indeed presents a V2 constraint necessitating verbal and constituent raising to $\mathrm{CP}$ in matrix declaratives. This will be carried out by means of an analysis of the quantitative and qualitative data from a late- $14^{\text {th }}$ century text, Navigatio Sancti Brendani $^{7}$. However, it will also be shown that this text is representative of a

$5 \quad$ In citing the text, the Arabic numeral refers to the relevant chapter.

$6 \quad$ Within this paper, V3* can be understood as encompassing V3, V4, and V5 orders.

7 The data sample was taken from Grignani and Sanfilippo's (1975) critical edition 
stage of old Venetian in which we can observe a gradual loss of the V2 constraint, following similar proposals by Benincà (1983) and Wolfe (2018) for later old Venetian and following a trend of recent proposals identifying old northern Romance as having a much more restricted V2 constraint (Ledgeway 2020, 2021; Wolfe 2020, 2021). This will be documented through the loss of Informational Focus in CP, the loss of scrambling, the development of subject clitics, and V-to$\mathrm{T}$ raising in embedded clauses. It will be proposed that these structures begun the reanalysis towards the SVO and lack of V-to-C raising that we find in unmarked declarative contexts in modern Venetian.

\section{Diagnostics for V2 in medieval Romance}

Within this section, we discuss the more common syntactic phenomena caused by the V2 constraint that we can use as diagnostics against which to corroborate the presence of said V2 constraint within a given medieval Romance variety or text. These diagnostics will later be used when qualitatively analysing the data from later old Venetian to propose that, whilst $\mathrm{V}$-to-C raising still holds in various contexts in matrix clauses, this is at a low frequency such to suggest that the constraint is being lost (see Benincà 1983 and Wolfe 2018 for similar proposals for later old Venetian), especially in light of recent proposals that point towards a more robust and uniform V2 constraint in earlier old (northern) Romance in which the phenomena that follow are highly attested (Ledgeway 2020, 2021; Wolfe 2020, 2021).

\subsection{Subject-verb inversion}

The first and, arguably, most important diagnostic that we can employ is that of subject-verb inversion. Namely, we expect the subject and verb to be inverted in those cases in which the phrasal constituent(s) that raises with the finite verb to $\mathrm{CP}$ is not the subject. This occurs whereby the constituent(s) and finite verb that raise to $\mathrm{CP}$ leave the subject in a lower position, resulting in an XP-V-S word order $^{8}$. Whenever the subject is overt and not the raised constituent, this inversion

of Navigatio Sancti Brendani. Tagliani (2014) corroborates to the fact that this text constitutes a volgarizzamento, or vernacular translation, directly translated from the Latin original. He also corroborates that the text is from the late $14^{\text {th }}$ century and is specifically old Venetian and not old Venetan. As one anonymous reviewer highlights, being translated from Latin, this translation of NSB could be argued to be representative of the emergence of the V2 constraint in Late Latin and not its loss in later old Venetian. Tagliani (2014:13) shows this not to be the case, highlighting that the text as being one of linguistic innovation when compared to the original, in stating that this translation of NSB "è connotato da un'evidente patina linguistica veneziana e presenta il testo più innovativo rispetto al modello latino [...], '[The translation] is characterised as being notably Venetian in linguistic origin and presents the most innovative text with respect to the Latin model'.

8 Whether this postverbal subject remains in situ in VP or itself raises to a higher projection is arguably subject to debate and possible parametric variation. Kaiser (2002) and Rinke (2007), in their respective studies on old French and old Portuguese, respectively, propose that instances of subjects occurring before past participles and other modifiers and arguments could be cases of vP-internal 
provides proof that elements otherwise first merged below the subject now raise above it, as demonstrated below:

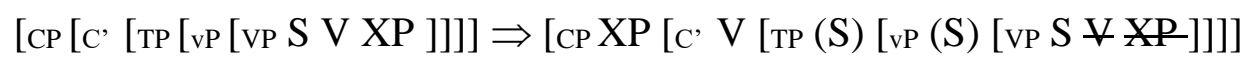

Instances of such inversion are very frequent within the literature on medieval Romance, as exemplified below in (3a)-(d):

(3) a. Si del campo bien salides, grand ondra auredes vos if from-the field well leave.2PL, great honour have.FUT.2SG you 'If you come out of the field well, you will be highly honoured'

(Old Spanish, Batllorí and Hernanz 2015:1)

b. A questo resposse Iasone (Old Neapolitan, Ledgeway 2008:440) to this replied.3sG Jason 'Jason replied to this'

c. A cel consel ot Nichodemus amis at that meeting had.3SG Nichodemus friends

(Old French, Adams 1987:4)

'Nichodemus had friends at that meeting'

d. E perciò sono le sue armi nere and thus are.3PL the his weapons black

'And for this reason his weapons are black'

Further parallels can be drawn to the Germanic languages with regard to $\mathrm{V} 2$ inversion structures in which the subject is found between the finite verb and non-finite forms in compound tenses and restructuring environments, as in (4) and paralleled in the old Tuscan example in (5):

$\begin{array}{lll}\text { Heute habe } & \text { ich mit ihm } & \text { gesprochen } \\ \text { today have.1SG I } & \text { with him } & \text { spoken } \\ \text { 'I spoke to him today' } & & \end{array}$

(German)
E per questi intendimenti ha
catuno trovata sua
legge and for these meanings has.3sG each found hi
'Through these meaning, each one has found his law'

(Old Tuscan, Poletto 2014:4)

As we will go onto see in \$3.2.3., inversion of the Germanic type is absent in these same environments in NSB, further shedding light on the more restricted makeup of the V2 constraint in later old Venetian.

subjects, whereby it is not clear how high the past participle raises in respective medieval Romance varieties. However, Poletto's (2014) study on old Italian finds cases of postverbal subjects before adverbs, which are assumed to fill an IPinternal position higher than the vP, as proposed by Cinque (1999). Similarly, Casalicchio \& Cognola's $(2018,2020)$ studies propose that two modern Ladin varieties may have either IP-internal or vP-internal subjects, based on a number of factors such as the discourse status of the subject and the specific constituent that is found in the preverbal position. 


\subsection{Informational Focus Fronting}

A second factor that we can use to evaluate the possible V2 status of a medieval Romance variety is that of Informational Focus Fronting (Lambrecht 1994; Vanelli 1998; Benincà \& Poletto 2004; Benincà 2006; et al.). Namely, this entails the raising of an informationally new, or rhematic, object to $\mathrm{CP}$, without clitic resumption. Notably, the presence of such structures has been used to argue in favour of the raising of the constituent at least as high as the Informational Focus projection within the $\mathrm{CP}$. This is attested throughout the old Romance corpora, as highlighted in (6a)-(c):

(6) a. Viechy reduceva ad etate iuvenile

old reduced.3sG to age juvenile

'and she could make the old young again'

(Old Neapolitan, Ledgeway 2008:440)
b. E
todo esto fazién él e sos fijos [...]
and all this did.3sG him and his sons
'He and his sons did all this...'

(Old Spanish, Rodríguez Molina 2010:1336)

c. Saluz vos=mande li bons chevaliers
greetings you=sends.3sG the good knight
'The good knight sends you his greetings'

(Old French, Marchello-Nizia 1999:44)

Notably, structures such as (6a-c) would not be permitted in most modern Romance varieties such as Italian whereby objects raised to the CP must either be a topic resumed with a clitic or an instance of contrastive focus; when informationally new, they are typically found in a postverbal position in unmarked contexts. Arguably, however, Informational Focus in CP is a diagnostic best considered in the context of diachronic and diatopic variation. Namely, as Ledgeway (2008, 2021), Poletto (2014), Wolfe (2018, 2020, 2021), et al., have noticed, it would seem that this strategy was more prevalent in earlier old northern Romance varieties, later being lost as they moved towards more fixed SVO orders through the loss of the V2 constraint. Notably, a few modern southern Romance varieties have retained this strategy: Sicilian, Sardinian, and Daco-Romanian (See Jones 1993; Cruschina 2006; Cruschina \& Remberger 2009; Remberger 2010) ${ }^{9}$. Crucially, these varieties do not present traces of V2. As such, it can be said that information focus allows us to account for non-resumed, non-topical XPs within a wider set of V2 phenomena.

\subsection{Scrambling}

A third factor that we can employ is that of scrambling, namely the non-canonical word order that occurs as a result of a modifying item appearing dislocated from

9 Informational Focus Fronting has been argued to exist in Basque Spanish, whereby Urrutia-Cárdenas (1988) and Sainzmaza-Lecanda (2016) posit the existence of such structures both in bilingual Basque-Spanish speakers and L1 Spanish speakers from the region. 
its syntactic head. First coined by Ross (1967) with specific reference to the phenomenon within Germanic, this is often used in the literature as a parallel between the V2 syntax of the Germanic languages (once again bar modern English) and old Romance (see Martins 2001, 2002; Ledgeway 2007; and Wolfe 2018 for more references). Note examples (7a-b), in which we find the direct object raising out of its postverbal base position above the past participle and/or finite verb.

\section{(7) a. I nimici avessero già il passo pigliato the enemies had.SUBJ.3PL already the=pass taken \\ 'The enemies had already occupied the pass'}

(Old Tuscan, Poletto 2014:40)

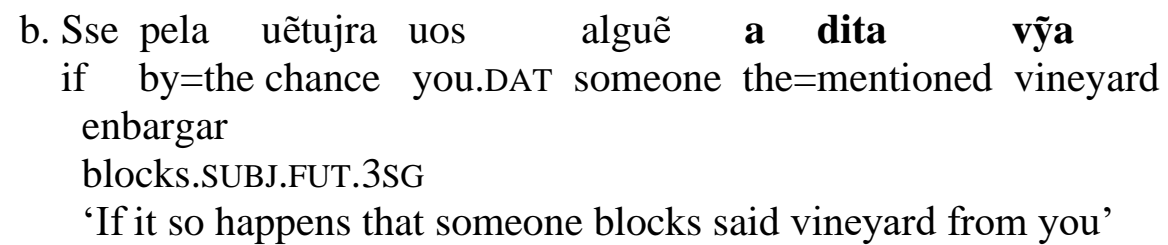

(Old Portuguese, Martins 2011:377)

Based off Poletto's (2006) analysis of scrambling in Old Italian, we might assume these scrambled elements that result in an OV word order move to a low focus position within the clausal lower left periphery, i.e. vP, à la Belletti (2004), as postulated below ${ }^{10}$ :

$$
[\mathrm{vp}[\mathrm{vP} \mathrm{V} \text { O]] } \Rightarrow[\mathrm{vp} \mathrm{O}[\mathrm{vp} \mathrm{V} \Theta]]
$$

Compare (7a-b), above, with (8) taken from Icelandic, in which the object DP bókina may raise higher than sentential negation which, in Germanic and unlike in Romance, is argued to mark the left edge of the v/VP (see discussion in Richards 2004 for more):

(8) Hvers vegna las Peter (bókina) ekki (bókina)?

why reads.3SG Peter the-book NEG the-book

'Why doesn't Peter read the book?'

(Icelandic, adapted from Vikner 1994:501-2, apud Richards 2004:2)

As such, we can use scrambling out of VP to $\mathrm{vP}$ as an important diagnostic tool in identifying the potential V2 status of a given medieval Romance variety.

\subsection{Asymmetric pro-drop}

It has been noted that old Romance varieties more readily licensed null subjects in matrix declarative clauses, as exemplified in (9a-c), than in embedded declaratives, in which they are mostly absent (see Benincà 1984; Vanelli et al. 1986; Adams 1987; Wolfe 2016, 2018; et al. ${ }^{11}$ ).

10 See Grewendorf (2005) for a similar proposal for the Germanic language. See also Jayaseelan (2001) and, Belletti \& Shlonsky (1995) for similar proposals for a low left periphery in modern Italian. 
(9) a. Lors li gita ses braz then him.DAT threw.3SG his arms

'After that, he threw his arms around him'

b. E così ne provò de' più cari ch' elli avea and thus PART=tested.3SG of-the most dear that=he had.3SG

'And so he tested some of the closest friends that he had'

(Old Tuscan, Benincà 2006:74)

c. Ané a sun premier ami, qui era munt rich went.3SG to his first friend, who was.3sG very rich 'He went to his first friend, who was very rich'

(Old Piedmontese, Wolfe 2016:9)

This asymmetry in the licensing of null subjects in embedded contexts has been proposed to be more present within old northern Romance, i.e. old GalloRomance and old (northern) Italo-Romance (see Benincà 1983; Vanelli, Renzi, \& Benincà 1985; Ledgeway 2020) ${ }^{12}$. Evidently, we note two asymmetries regarding the distribution of the V2 parameter between matrix and embedded clauses: the asymmetry in null subjects affecting old northern Romance, and the asymmetry in the general availability of V-to-C movement, as discussed in $\$ 1.1$. Given that null subjects do not occur in those contexts in which V-to-C movement is blocked, we can assume that the availability of pro in matrix declarative contexts in old northern Romance is related to its ability to raise to $\mathrm{CP}$, as first proposed by Benincà (1984) and Adams (1987).

\subsection{Enclisis of clitics}

A final diagnostic that we can employ is that of cases of enclisis of object clitics in V1 clauses. Notably, following Tobler (1875) and Mussafia (1888) and the subsequently named Tobler-Mussafia Law, it has been observed that reflexive and object clitics are excluded from the initial position in medieval Romance whereby they occur in enclisis attached to the finite verb in V1 orders. This is often used as a hallmark for $\mathrm{V}$-to-C raising whereby it corroborates the movement of the finite verb to this clause-initial position. Notably, in some old Romance varieties, the presence of conjunctions such as 'and' and 'but' may also result in clitic enclisis, as in $(10)^{13}$ :

Italian whereby they note that null subjects were more frequently licensed in matrix declarative contexts in both varieties.

12 One anonymous reviewer questions whether the diatopic distribution of this asymmetry has been tested against a significant dataset. Whilst any ponderings on this are beyond the scope of this study, arguably more research is necessary on this distribution based on a wider dataset.

13 As Benincà (2004:274) highlights there is a parametric variation in whether the presence of coordinating conjunctions cause proclisis or enclisis of the clitic. She notes that the latter is representative of old Florentine, Venetian, southern ItaloRomance varieties and old Spanish and Portuguese. The former, however, would seem to be representative of old French, Piedmontese and Lombard. 
E vavisi per una via molto stretta e per

and goes.3SG=LOC. $=$ REFL . by a street very narrow and through

una piccola porta $\mathrm{vi}=\mathrm{s}^{\prime}=\mathrm{entra}$

a small door LOC. $=$ REFL. $=$ enters. $3 \mathrm{SG}$

'One goes there through a very narrow street and enters there through a small door'

(Old Tuscan, Poletto 2014:18)

\section{Verb second in old Venetian}

\subsection{The quantitative data}

Based purely on the statistical data pulled from the 1258 un-coordinated matrix declarative clauses present within the 44-page text Navigatio Sancti Brendani, we see that the majority of matrix clauses present superficial V2 orders $^{14}$.

Table 1. the position of the finite verb in matrix clauses in $\mathrm{NSB}^{15}$

\begin{tabular}{|c|c|c|c|c|}
\hline & $\begin{array}{c}\text { Transitive } \\
\& \\
\text { Unergative }\end{array}$ & Unaccusative & Athematic & Total \\
\hline $\boldsymbol{V 1}$ & $18(3.4 \%)$ & $65(12.2 \%)$ & $14(6.5 \%)$ & $97(7.7 \%)$ \\
\hline $\boldsymbol{V} \mathbf{2}$ & $\begin{array}{c}258 \\
(49.3 \%)\end{array}$ & $329(61.7 \%)$ & $127(59.3 \%)$ & $714(56.7 \%)$ \\
\hline $\mathbf{V 3}^{*}$ & $\begin{array}{c}235 \\
(47.3 \%)\end{array}$ & $139(26.1 \%)$ & $73(34.2 \%)$ & $447(35.5 \%)$ \\
\hline TOTAL & $\begin{array}{c}511 \\
(40.9 \%)\end{array}$ & $533(42.7 \%)$ & $214(17.1 \%)$ & 1258 \\
\hline
\end{tabular}

Once again, based on the crude statistical data observed in table 2 below, superficial V2 is most frequent word order displayed by in this corpus' 273 embedded clauses, occurring at a striking $90.4 \%$. Thus, at least based on the superficial data, our expectation that we find SVO orders in embedded clauses due to the inability for the verb or constituent to raise to $\mathrm{C}$ could be said to be borne out whereby the presence of the overt complementizer blocks movement to the verbal left periphery.

14 Note that the data was categorised based on: (i) the superficial clausal position of the finite verb (V1, V2, V3, etc.), and (ii) the verb type; namely, by transitive, unaccusative and athematic predicates. The latter was employed $a ̀$ la Ledgeway $(2008,2021)$, whereby it refers to those predicates that do not assign an external or internal argument, instead inheriting their argument structure from their nonfinite complements. In the case of our $14^{\text {th }}$ century old Venetian text, these verbs include the modal verbs poder 'can', dever 'must', and voler 'want' and aspectual verbs such as comenzar 'begin'.

15 A chi-square test of independence was performed whereby the relationship between verb type and word order in main clauses was found to be significant, $x^{2}$ $(1, \mathrm{~N}=1258)=61.3, p=<0.5$. Notably, in embedded clauses, this relationship was found to be not significant, $x^{2}(1, \mathrm{~N}=273)=.127, p=<.05$. 
Table 2. The position of the finite verb in embedded clauses in NSB

\begin{tabular}{|c|c|c|c|c|}
\hline & $\begin{array}{c}\text { Transitive \& } \\
\text { unergative }\end{array}$ & Unaccusative & Athematic & Total \\
\hline V1 & $3(3.9 \%)$ & $7(6.1 \%)$ & $3(3.9 \%)$ & $13(4.8 \%)$ \\
\hline $\boldsymbol{V} \mathbf{2}$ & $74(89.2 \%)$ & $106(93.0 \%)$ & $67(88.1 \%)$ & $247(90.4 \%)$ \\
\hline $\boldsymbol{V 3} *$ & $6(6.9 \%)$ & $1(0.9 \%)$ & $6(8.0 \%)$ & $13(4.8 \%)$ \\
\hline TOTAL & $83(30.4 \%)$ & $114(41.8 \%)$ & $76(27.8 \%)$ & 273 \\
\hline
\end{tabular}

However, such crude statistical data is inadequate in corroborating the existence of a V2 constraint in old Venetian, namely whereby the SVO orders found in the majority of matrix clauses would also yield a similar number of superficial V2 clauses in modern non-V2 Romance varieties. The data that we have seen above is best understood through a qualitative approach that considers each clause type as well as the pragmatic functions of the constituents and the resulting word order. In what follows, I will analyse this corpus' qualitative data to the ends of corroborating the presence of the V2 constraint within old Venetian.

\subsection{The qualitative data}

\subsubsection{Constituent fronting in old Venetian}

An in-depth analysis and understanding of the qualitative data and the pragmatico-semantic functions of certain word orders first necessitates a look at the constituents that we find before the superficial V2 orders found within the text. As seen in table 3, below, the subject was the most common pre-verbal constituent occurring in $62.3 \%$ of the 704 superficial V2 matrix clauses within this text. Arguably, these occurrences are akin to the SVO orders found predominantly in non-V2 modern Romance varieties. However, note that within the Germanic languages, in which the V2 constraint has been long attested, subject-initial clauses have also been found to account for the majority of overall matrix clauses ${ }^{16}$.

A closer look at table 3 , below, shows a series of preverbal constituents that prove that this preverbal field was not an exclusive subject position in old Venetian. Rather, in line with what has been argued for medieval Romance (Benincà 1995; Ledgeway 2008, 2020; Poletto 2014; Wolfe 2018; et al.), we see that his preverbal field can host a wide number of grammatical categories:

16 Lightfoot $(1993,1995,1997,1999)$ notes that SVO accounts for around $70 \%$ of matrix clauses in V2 varieties. Similarly, Yang (2000) notes that only around $23 \%$ of matrix clauses in Dutch are non-subject initial clauses. See Wolfe (2018:24) for more statistics on non-subject initial clauses across Germanic and respective readings. 
Table 3. Fronted pre-verbal constituents in V2 matrix clauses in NSB ${ }^{17}$

\begin{tabular}{|c|c|}
\hline Constituent type & Occurrence \\
\hline Subject & $439 / 704(62.3 \%)$ \\
\hline Direct objects & $5 / 704(0.7 \%)$ \\
\hline Dative objects & $13 / 704(1.8 \%)$ \\
\hline Prepositional phrases & $22 / 704(3.1 \%)$ \\
\hline Locative complements & $83 / 704(11.7 \%)$ \\
\hline Adverbial phrases & $114 / 704(16.2 \%)$ \\
\hline Sì & $28 / 704(3.9 \%)$ \\
\hline
\end{tabular}

After the subject, the most common preverbal constituent was adverbial phrases, such as that in (11a), and locative complements, as exemplified in (b):

$\begin{array}{cll}\text { (11) a. E } & \text { ancuò } & \text { è domenega } \\ \text { and } & \text { today } & \text { be.3SG Sunday }\end{array}$

(NSB, 27)

'Today is Sunday'

b. $\mathrm{E}$ in questa isola va speso l'=abado

and in this island goes.3SG often the $=$ abbot

Mernoc $[\ldots](\mathrm{NSB}, 1)$

'The abbot Mernoc often goes to this island'

Mernoc

Instances of prepositional phrases, as in (c), dative objects, as in (d), and the particle sì (e) were less frequent:

c. E de zo fa ricordanza lo profeta Davit

(NSB 38) and of that makes.3SG remembrance the=prophet David in un verso $[\ldots]$

in a verse

'The prophet David makes reference to that in a verse...'

d. A vui non è lizita cosa a doverve partir to=you NEG is.3SG lawful thing to must=REFL. depart

$(\mathrm{NSB}, 14)$

'You are not allowed to leave'

e. E sì co' la luna riceve lume dal sol and sì with the $=$ moon receives 3 light from=the sun 'The moon receives light from the sun'

Those preverbal constituents with the lowest attestations were rhematic objects, whereby only five attestations were found within superficial V2 matrix clauses, an example of which we see in (f):

f. E lo nadal dové far ogni ano defina la= and the $=$ Christmas must.2PL do every year until the $=$ otava de Pifania con la=fameia de lo abado Albeo eighth of Pentecost with the=family of the abbot Albeo

(NSB, 16)

17 Note that XPs resumed by clitics have been excluded from this breakdown. 
in lo so monastier

in the his monastery

'You ought to celebrate Christmas every year, from the eighth of the

Pentecost, with the family of Abbot Albeo in his monastery'

In what follows, I will look at and analyse instances of further phenomena related to the V2 constraint in old Venetian against the V2 diagnostics established in section 2. By means of a qualitative and comparative analysis of these V2 phenomena, it will be proposed that this text is representative of a stage of later old Venetian in which the V2 constraint was heavily restricted such as to be indicative of its incipient loss within the variety.

\subsubsection{Informational Focus in old Venetian}

As discussed in \$2.1., Informational Focus Fronting comprises those rhematic, or informationally new, objects that are raised to the Informational Focus projection within CP. Notably, within medieval Romance, these occur without clitic resumption. As previously noted in table 3, these structures, as in (11f), are very rare within our corpus, with only five overall attestations in matrix clauses. It would seem that Informational Focus structures, such as (12), were typical of earlier stages of old Romance whereby their licensing in the later stages of old northern Romance is notably limited, which is in line with similar proposals in more recent literature on the so-called North-South divide within Romance with particular reference to the V2 constraint (Ledgeway 2020, 2021; Wolfe 2020, 2021).

(12) Falsa testimonianza contra 'l=prossimo false testimony against the=neighbour

'You shall not perjure your neighbour' tuo non porterai

your NEG bring.FUT.2SG

(Old Tuscan, Poletto 2014:9)

The small percentage of these structures within Navigatio Sancti Brendani show that these constructions were no longer readily licensed in old Venetian by the fourteenth century, similar to Wolfe's (2018) findings on the early $14^{\text {th }}$ century old Venetian text I monumenti del dialetto di Lio Mazor, whereby some $1.32 \%$ of the text's matrix V2 clauses were fronted by a rhematic object. In brief, the loss of this phenomenon casts further insight into the workings of the V2 constraint in this variety, particularly the functional projections to which the verb and constituent could raise. These have been shown to be heavily restricted in later old Venetian and indicative of a similar trend within later stages of old northern Romance.

\subsubsection{Subject-verb inversion in old Venetian}

As we saw in $\$ 2.1$, in medieval Romance, the raising of a constituent other than the subject gives rise to subject-verb inversion. Here, it is necessary to distinguish between pronominal and lexical inverted subjects, whereby instances of the latter, exemplified in (3b-c), were almost absent in this text. This is due to: (i) the high number of subject-initial clauses and to the high proportion of $\mathrm{V} 3$ orders in matrix clauses in which the subject was the second clausal element, which accounted for a large number of the overall matrix clauses in this corpus; and, (ii), to the fact that, as we will see in \$3.2.6, old Venetian was a asymmetric pro-drop variety in 
which null subjects were more readily licensed in main clauses and absent in embedded contexts.

Notably, subject-verb inversion with pronominal subjects is obligatory in this text in interrogative contexts, mirroring what we find in the modern northern Italian dialects. There were no instances of such clauses without a pronominal subject immediately following the finite verb, as exemplified in (13a-c):
(13) a. Vedé=vu quela isola ch' io vego da lonzi? see.2PL=you that island that $=\mathrm{I}$ see. $1 \mathrm{SG}$ from far
'Do you see that island that I see from afar?'

b. Fiol mio, non te $=$ recordes $=$ tu quante grazie Dio (NSB, 19) son my, NEG you=remember.2sG=you how.many favours God ne à dade in questo viazo? [...] us=has.3sG given in this journey?

'My son, do you not remember how many favours God has given us on this journey? [...]'

c. O pare, chi es- tu?

oh father, who are.3sG=you?

(NSB, 24)

'Oh father, who are you?'

As we will go onto see in $\S 3.2 .4$, these inverted pronominal subjects arguably attest the cliticization of tonic subjects to subject clitics that are now characteristic of modern Venetian.

Moreover, cases of Germanic inversion of the type: constituent-auxiliarysubject were notably absent within this text in compound tenses and restructuring environments, whereby these subjects almost always occur preverbally even after initial constituents, as in (14a-b):

(14) a. E de presente san Brandan li comenzà a confortar (...) (NSB, 4) and of present saint Brendan them=began.3 to comfort

'And in that moment, Saint Brendan began to comfort them'

b. E in quela fiada, quando fo dito queste parole,

$(\mathrm{NSB}, 1)$ and in that time, when was. 3 said these words, lo dito abado Barinto sì comenzà a dir parole de una isola the said abbot Barinto sì began.3 to say words of an island 'Then, once this was said, said Saint Barinto began to speak of an island'

It could be pointed out, as one anonymous reviewer has, that the lack of fully-fledged inversion of the Germanic type, as in (14a-b), could lead to preverbal constituents other than the subject being interpreted as cases of stylistic fronting, following the minority in the V2 literature who propose this is the case (cf. Kaiser 2002, Rinke 2007, Sitaridou 2012). However, as Franco $(2009,2014)$ highlights in her various studies on stylistic fronting and inversion structures in old Italo-Romance, such fronting involves head-like elements (e.g. participles, infinitives), and not phrasal constituents. There is also the further condition to stylistic fronting that the verb be unaccusative, passive, or a restructuring 
predicate. Notably, these conditions do not hold in NSB, thus meaning that we can exclude a stylistic fronting analysis for these structures.

\subsubsection{Preverbal subjects}

As noted in table 3, above, the data from Navigatio Sancti Brendani shows a strong preference for the subject as the preverbal constituent, whereby almost $65 \%$ of matrix clauses were fronted by the verbal subject. Again, this does not go entirely against the findings for Germanic (see fn.16) and for old Italo-Romance, including those from Lio Mazor in Wolfe (2018), as we can see in table 4, below:

Table 4. Attestations of subject-fronted clauses in old Italo-Romance varieties

\begin{tabular}{|c|c|}
\hline Variety & \% of subject-initial matrix clauses \\
\hline Old Venetian & $74.3 \%$ \\
\hline Old Sardinian & $62.6 \%$ \\
\hline Old Sicilian & $47.6 \%$ \\
\hline Old Neapolitan & $22.8 \%$ \\
\hline
\end{tabular}

Source: Ledgeway (2007:124) for old Neapolitan and Wolfe (2018:25) for old Venetian, old Sardinian and old Sicilian.

A further breakdown of those instances of preverbal subjects shows a higher-thanexpected preference for pronominal subjects if we assume that, much like the rest of old Romance, this stage of old Venetian represented -at least in matrix contexts- a pro-drop language. In 193 of the 439 subject-fronted V2 clauses $(43.9 \%)$, the subject was pronominal in form and topical in nature in clauses featuring all three verb types analysed, such as the examples in (15a)-(c):

(15) a. Nui posemo tuti perir per questo pecado

$(\mathrm{NSB}, 6)$ we can.1PL all perish for this sin

'We could all perish for this sin'

b. E vui savé l' angustia de lo mio cuor e

and yu.PL know.2SG the=anguish of the=my heart and

(NSB 10)

la $=$ mia volontade

the $=$ my will

'You know the anguish and will of my heart'

c. E eli desmontà de la=nave and they disembarked. 3 from the=ship

'They disembarked from the ship'

When we compare (15a)-(c) to the obligatory use of these pronouns in interrogative contexts seen in (13a)-(c), we see that their distribution is seemingly more obligatory than subject pronouns in full null subject languages. Arguably, these pronouns are representative of the weakening of these once tonic subjects to the subject clitics that we now find in modern Venetian, which corroborates the proposal by Benincà et al. (2016:199) that said cliticization occurred around the $15^{\text {th }}$ century (see also Vanelli, Renzi, and Benincà 1985 and Vanelli 1997).

There are a few noteworthy observations to make on the distribution and form of these weak subject pronouns. Namely, typological literature on the distribution of subject clitics in the modern northern Italian dialects tends to 
highlight the following scale of implication, whereby it is common for the modern varieties to not display full subject clitic paradigms in declarative contexts (see Vanelli 1997 and Pescarini 2016):

$$
2 \mathrm{SG}>3 \mathrm{SG}>3 \mathrm{PL}>2 \mathrm{PL}>1 \mathrm{PL}>1 \mathrm{SG}
$$

(Obligatory) (non-obligatory)

According to this scale, it is expected that, should a given variety have an incomplete subject clitic paradigm, it is most probable that it will have those on the obligatory end of the scale. Of interest to this particular study on old Venetian is that the most common subject pronouns that occur are those of the $3^{\text {rd }}$ person plural, $2^{\text {nd }}$ person plural, $1^{\text {st }}$ person plural, and $1^{\text {st }}$ person singular, which are those with lower frequencies in modern Venetan dialects. Furthermore, modern Venetian derives its $1 \mathrm{SG}$ subject clitic from Latin MIHI. However, 1SG subject pronouns in NSB were limited to io (<Lat. EGO), similar to findings from Benincà (1994:17) on Lio Mazor. Arguably, this is an area of old Venetian syntax that requires more investigation and research.

Overall, it seems reasonable to conclude overall that these subject pronouns were in a process of weakening to the subject clitics that we find in modern Venetan varieties, with some notable differences in morphological form and distribution that undoubtably require further research.

\subsubsection{Expletive elo and si}

The expletive pronoun $e l(l) o$ (lo in reported speech within the corpus) is found frequently within Navigatio Sancti Brendani. We see examples of this in (16) in which we can observe a lack of agreement between elo and its feminine singular referent l'osiela 'the bird':

(16) E voiando li frari intrar in nave per andar via,

(NSB, 13) and wanting the monks enter in ship for go away,

elo vene l' osiela volando viazamentre su la proda de la nave EXPL came. 3 the=bird flying quickly on the bow of the ship

'Whilst the monks attempted to enter the ship to get away, the bird came flying quickly over the edge of the ship'

Compare the expletive neuter $i l j$ from Surselvan, a non pro-drop Romance V2 variety, as in (17), below $^{18}$ :

$\begin{array}{lll}\text { (17) } \underline{\text { Ilj }} \quad \text { ej } & \text { bi } \\ \text { EXPL is.3sG } & \text { well } \\ \text { 'It is good' } & \end{array}$

(Surselvan, Benincà \& Haiman 1992:131)

Notably, we only find instances of elo with the postverbal subjects of unaccusative verbs, as in (18a- b), and whenever these subjects, which we can assume to be underlying objects, following Perlmutter (1978), are rhematic in nature. This confirms the intuition in §3.2.2. that preverbal Informational Focus in

18 Also see Manzini \& Savoia 2005: vol.1 for an extensive discussion on expletive clitics with postverbal subjects in the northern Italian dialects. 
$\mathrm{CP}$ is not ready licensed in old Venetian. Rather, on par with modern Romance, rhematic objects are to be found mostly in a postverbal position.

(18) a. E in pizola ora elo vene ancora tal caligo

$(\mathrm{NSB}, 1)$ and in little hour EXPL came. 3 again such fog

'Soon after came another such fog'

b. E in pizola spazio, da ch'=elo ave fato and in small space, from that=he had.3 made questo comandamento, elo li vene xi munegi this commandment EXPL him.DAT=came. 3 eleven monks incontra da lutan against from far 'Soon after he had made this commandment, eleven monks approached him from afar'.

Expletive elo is found in complementary distribution with si with these informationally new objects, as in (19a)-(b):

(19) a. E abiando ordenado enfra nu' queste cose sì 'nde=

$(\mathrm{NSB}, 1)$ and having ordered amongst us these things sì part= aparete uno omo dananti molto bello appeared.3 a man before very beautiful 'Having decided these things amongst ourselves, there appeared a very beautiful man before us'

b. E sì li= vene uno bon vento per aiutorio $(\mathrm{NSB}, 8)$ and sì them=came. 3 a good wind for assistance 'And so came a good gust of wind to help them.

Notably, whenever the object is instead topical, we instead find a subject in a preverbal position, which is in complementary distribution with both si and elo, as exemplified in (20a- b):

(20) a. E in quella fiada nui desmontasemo de la nave in tera (NSB, 1) and in that time we disembarked.1PL from the ship in land

'At that moment, we disembarked from the ship onto the shore'

b. E abiando cusì dito, quelo tornà indriedo

$(\mathrm{NSB}, 12)$ and having so said, that returned.3 back

'And having said that, he headed back'

Regarding sì specifically, within our corpus, instances of sì were limited to 99 matrix clauses and 5 embedded clauses. The most significant use of sì was found in those clauses in which it is the first clausal constituent and in which the postverbal object is informationally new, which represented $26.9 \%$, or $28 / 104$ clauses, of its overall distribution, as discussed in $\$ 3.2 .4$ and further exemplified in $(21)$ : 
(21) $\mathrm{E}$ sì mese uno albero in mezo de la nave

$(\mathrm{NSB}, 3)$ and sì put.3 a tree in middle of the ship

'And he put a tree in the middle of the ship'

Occurring in 19/104 of the overall clauses in which sì was present, or rather $18.3 \%$ of these attestations, was the use of sì with an initial scene-setting element and a rhematic object, as in (22):

(22) Et in cavo de li tre mesi sì vene uno di in lo qual and in end of the three months sì came. $3 \mathrm{a}$ day in the which

$(\mathrm{NSB}, 14)$

li aparse una isola [...]

them=appeared. 3 an island

'At the end of the three months, there came a day in which an island appeared them $[\ldots]$ '

As we have previously seen, in both contexts, sì is in complementary distribution with expletive elo.

Moreover, following Wolfe's (2018) proposal that the clause-initial scene setting elements are first merged in the Frame projection of CP, we can assume that these elements do not satisfy the phrasal requirement of the V2 constraint that necessitates either external or internal merge to CP. Thus, we can understand examples such as (22) to be orders in which sì is the first clausal element as far as the V2 constraint is concerned, whereby it is externally merged in CP to satisfy the phrasal constraint. This is further confirmed by the fact that the external merging of sì or elo is restricted to matrix clauses, meaning that they are merged whenever the V2 constraint is active. We can assume that the text at hand represents a transitional period in which both si and elo were merged in complementary distribution to satisfy this requirement. We observe two operations to satisfy the phrasal requirement of the V2 constraint when we have postverbal objects and whose distribution is directly fed by the pragmatics: if the object is rhematic, expletive elo or si are externally merged, as in (23a). If the object is topical, the subject is internally merge, as in (b), whereby said subject could be argued to raise to a Spec position within the Topic projection. In embedded contexts, where we assume the absence of an EPP requirement on $\mathrm{CP}$, we do not find the internal nor external merge of such elements, as in (c):
(23) a. [cР elo/sì [C, V
[TP (S) [vp S $\forall \mathrm{O}]]]$
b. $\left[\mathrm{CP} S \quad\left[\mathrm{C}^{\prime} \mathrm{V} \quad[\mathrm{TP} \quad[\mathrm{VP} \mathrm{S} \vee \mathrm{O}]]\right]\right.$
c. [cP che [TP S V [

Thus, the data above sheds further light on the interplay between syntax and pragmatics in old Venetian. Namely, we see that, for example, whilst Informational Focus in $\mathrm{CP}$ is heavily restricted, the merging of elements in the Topic projection of $\mathrm{CP}$ is still a productive process at this stage of later old Venetian. 


\subsubsection{Asymmetric pro-drop in old Venetian}

As discussed in $\$ 2.4$, an asymmetry in the availability of null subjects has been observed in old Gallo- and old northern Italo-Romance whereby pro is mainly absent in embedded contexts. In NSB, this asymmetry is notably very reduced, whereby null subjects in matrix clauses are limited to instances of topic continuity, as exemplified by (24), below:

(24) O pare, vui staré ancuò qua e faré quelo che vui oh father, you stand.FUT.2PL today here and do.FUT.2PL that which you avè a far [...]. Mo doman per tempo seré in quela isola have.2PL to do [...]. But tomorrow for time be.2PL in that island [...] la qual vui vedé $[\ldots]$ the which you see.2PL

'Oh father, you will stay here today and will do that which you have to do [...]. However, tomorrow, for a time you will be on that island [...], that you can see (over there)'

$(\mathrm{NSB}, 8)$

Notably, this finding contrasts greatly with Wolfe's (2018) analysis of the early $14^{\text {th }}$ century text I monumenti del dialetto di Lio Mazor, in which null subjects were present in almost half of the overall matrix clauses.

\subsubsection{Scrambling and 'ben' fronting}

There were very few instances of scrambling found within NSB, which is noteworthy when compared with higher attestations of this phenomenon in the corpora and analyses of other (earlier) old Italo-Romance varieties (c.f. Ledgeway 2008 on old Neapolitan; Wolfe 2018 on old Sicilian; among others). These instances of scrambling are limited to the direct object raising to vP, as in (25a-b):

(25) a. E ben te à Dio tal cose mostrade

(NSB, 19) and ben you= has. 3 God such things shown

'God has indeed showed and allowed you to see such things'

b. Ben avemo tante cose vezudo e sapudo e tocado (NSB, 43) ben have.1PL many things seen and known and touched che non può ben bastar that NEG can.3 well suffice

'We have indeed seen, known, and touched so many things, that it cannot be enough'

Here diachronic parallels are to be drawn, particularly with those stages of medieval Romance undergoing a loss of the V2 system. Poletto's (2014) study of old Italian finds scrambling to be almost absent in later texts that show 'very little trace of the former V2 system'. It would, therefore, seem that the low attestations of scrambling within our text have clear parallels within old Italo-Romance and are further indicative of an incipient loss of the V2 constraint within later old Venetian.

Another striking phenomenon that we do find and that is also represented in (25a-b) is that of the fronting of adverbial ben to the preverbal position. Notably, Cognola and Schifano $(2018,2020)$ interpret ben in both modern and old Venetan varieties as a polarity presuppositional item used to deny the 
interlocutor's negative presupposition and not synonymous with the IP adverb bene 'well'. In their study of the later old Venetian text Lio Mazor, they only found instances of ben within the IP area. In NSB, arguably there are two positions available to ben: a CP position, as in (24a)-(b), and an IP-internal position (proposed by the Cognola and Schifano to be PresuppositionalP within the negation area), as in (26a)-(b), below:

(26) a. Non sas- tu ben che nui avemu abandoado parenti [...]? (NSB, 2) NEG know=you ben that we have.1PL abandoned relatives

'Do you not know full well that we have abandoned our relatives?'

b. E iera 'nde de pizole e de grande lusierte che coreva and was. 3 there of small and of big lizards that ran.3

de qua e de là $(\ldots)$ che ben non se po' dir nì scriver of here and of there (...) that well NEG REFL=can.3 say nor write

'There were small and large lizards that ran here and there that I cannot describe well'.

This could suggest that NSB represents a mixed system in which both positions are available for ben. Notably, in NSB, this adverb may still raise to CP, shedding further light on the productivity of the V2 constraint in later old Venetian and the type of constituents that could raise to this position.

\subsubsection{V1 orders and clitic enclisis}

As seen in table 1, V1 orders constitute a not insignificant albeit infrequent word order in the matrix clauses found within our corpus, representative of $7.7 \%$ or $97 / 1258$ matrix clauses. Its distribution is notably limited to instances of topic continuity, as in (27):

(27) E conmenzasemo a navegar e in pizola ora elo

and begun.1PL to navigate and in small hour EXPL

$(\mathrm{NSB}, 1)$ ne $=$ vene ancora tal caligo us $=$ came. 3 PL still same fog

'And so we begun to sail and, soon after, another fog came upon us again'

We can assume that pro is able to raise to possibly $\mathrm{CP}$ and satisfy the phrasal EPP requirement on CP by lexicalising a relevant Spec position, within C, as proposed by Benincà (1984) and Adams (1987) and as illustrated below. Given the pragmatically marked nature of these orders, it is possible that pro raises to the Topic projection specifically within CP.

$$
[\mathrm{cP} p r o[\mathrm{C}, \mathrm{V} \ldots[\mathrm{vp} S \forall \mathrm{O}]]]
$$

As previously discussed in $\$ 2.5$. and in relation to the V1 orders discussed above, a further diagnostic that we can employ in order to evaluate the V2 status of later old Venetian is that of clitic enclisis. Namely, we expect object and reflexive clitics not to occupy the initial clausal position bar a few exceptions, such as those of coordinating conjunctions. This is indeed the case in this text, as in $(28 \mathrm{a}-\mathrm{b})$ : 
(28) a. Elo à tolto uno fren d'=arzento e à=lo scoso
he has. 3 removed a lever of=silver and has.3=it shaken
in sen de lo diavolo
in bosom of the devil
'He withdrew a silver arrow and stuck it in the devil's bosom'

b. E puo' morirà e partirà=se l'=anema $\quad(\mathrm{NSB}, 6)$ and then die.FUT.2SG and leave.FUT.3SG=REFL. the $=$ soul toa dal corpo your from=the body

'Then you will die and your soul will leave your body'

Whilst V1 orders are infrequent within this text, it holds that we find enclisis whenever these occur with clitics. Benincà's (2004) proposal that clitic enclisis in V1 orders is triggered by $\mathrm{V}$ in $\mathrm{C}^{\prime}$ and an empty Focus would seem to hold, whereby she proposes that further verbal raising operation occurs to the left of the initial landing site of the verb, 'to reach the head whose Spec a Topic (LD or HT) is base generated'. Such a movement operation, as exemplified below, could easily account for the data regarding V1 orders and enclisis in NSB:

[CP [HT e [C1 [C2 lo à .... [vP to à scoso in sen de lo diavolo]]]]]] $\Rightarrow$ [CP [нт e [C1 à [C2 lo ta .... [vp to à scoso in sen de lo diavolo]]]]]]

Notably, whilst the overall trend within this text is that of an infrequency and arguable loss of hallmark V2 characteristics, enclisis in V1 orders is a context in which the V2 constraint can be seen as still being productive in later old Venetian.

\subsubsection{V3* orders and embedded clauses}

A body of work (Benincà 1983, Ledgeway 2008, 2009; Wolfe 2015, 2018; et al.) argues in favour of a distinction between rigid V2 and so-called lax V2. The former is exemplified by continental Germanic whereby there may only be one preverbal constituent, rendering V3* and V1 orders mainly ungrammatical ${ }^{19}$. The latter, on the other hand, is exemplified by old Romance, whereby these divergent $\mathrm{V}^{*}$ and $\mathrm{V} 1$ orders are found frequently within the corpora, subject to diachronic and diatopic variation.

Within our late $14^{\text {th }}$ century corpus, V3* orders account for $35.8 \%$ of overall attested orders within matrix clauses. V3 orders were found in 392, or $87.7 \%$, of these clauses, with attestations of V4 resulting very marginal within the

19 Note that V3 orders are not unheard of within continental Germanic. Weise (2009), Walkden (2017), Alexiadou \& Lohndal (2018) et al., for example, report on the presence of V3 orders in Germanic urban vernaculars and in the speech of heritage speakers, as in (ii), below. Arguably, however, this is the output of two grammars within bilingual speakers rather than representing a phenomenon similar to the V3 orders found within our text.

(ii) Morgen ich geh arbeitsamt tomorrow I go.1SG job.centre

'Tomorrow I will go to the job centre'

(Kiezdeutsch, Weise 2009:787) 
corpus. All of the $392 \mathrm{~V} 3$ orders were made up of the sentences previously seen in \$3.2.5., namely in which we find: an initial scene-setting element -assumed to be base generated within the Frame projection of CP-, the subject/elo/si, and the finite verb, as illustrated in (29). As such, these clauses can be interpreted as V2 clauses par excellence.

(29) E in quela fiada san Brandan con tuta la soa conpagnia

$(\mathrm{NSB}, 8)$ and in that time saint Brandan with all the his company

andà navegando in qua $\mathrm{e}$ in la per mar per spazio di tre mesi went. 3 navigating in here and in there by sea for space of three months 'And in that moment, saint Brendan along with his followers, continued to sail all over the seas for a period of three months'.

Wolfe's (2018) study of Lio Mazor has similar findings, where V3 orders accounted for almost $30 \%$ of the matrix clauses within the corpus, with Frame elements representing the only constituents in the initial clausal position. This data also has parallels within old Romance and later old English; Sitaridou's (2012) analysis of word order in old Romance finds frequent orders of this type in old French, as in (30):

(30) Quant il= furent armé, li dux (Old French, Sitaridou 2012:567) when they=were.3PL armed, the duke

parla à tous les haus hommes de l'=ost

spoke to all the high men of the=army

'Once they were armed, the duke spoke to all of the high men within the army'

With regard to V3 orders in old English (see Koopman 1998; and Haeberli 1999, 2000), Haeberli's (2000) analysis of old English found these clauses, as shown in (31), to represent almost $30 \%$ of overall clauses within their corpus.

(31) Efter his gebede he ahof paet cild up (OEng, van Kemenade 1987:110) After his prayer he lifted.3SG that child up

'After his prayer, he lifted that child up'

In brief, we see that V3 orders are of a high frequency within our corpus and are to be considered an extension of the superficial V2 orders, whereby, as we have seen, the initial Frame elements that are clause-initial may not satisfy the V2 constraint.

Regarding embedded clauses within our text, as mentioned, we find an asymmetry between matrix and embedded clauses whereby V2 fails to obtain in the latter leading to an SVO order in these clauses due to the presence of an overt complementiser blocking V-to-C movement, as in (32a-c), below:

(32) a. Alò Santo Brendan comandà a tuti then Saint Brendan commanded.3 to all ch' eli non trazese alguna cosa fuora de la nave that=they NEG carry.SUBJ.3 any thing outside of the ship 'Saint Brendan then commanded them not carry anything off of the ship'. 
b. E san Brendan clamà li suo' frari e comandà=li and Saint Brendan called. 3 the his friars and ordered. $3=$ them ch'=eli toia seguramente de queste bestie that=they take.SUBJ.3 securely from these beasts

'Saint Brendan called his friars and ordered them to take safely from these beasts'

c. E pareva ch'=ela vegnise viazamente driedo eli and seemed. 3 that=she came.SUBJ. 3 quickly behind them per devorar $=\mathrm{li}$ for eat=them 'It seemed that she was coming up behind them quickly in order to eat them'

As previously discussed, we can attribute the asymmetrical distribution of null subjects, as in (32c), to the ability of pro to raise to CP.

Whilst it is evident that $\mathrm{V}$-to- $\mathrm{C}$ raising fails to hold in embedded contexts, attestations such as (32b-c) highlight that the finite verb and subject raise to clause-internal positions. If we assume adverbs such as seguramente 'safely' and viazamente 'quickly' to lexicalise the TP, following Cinque's (1999) seminar work on the matter and subsequent cartographic works on verb movement in Romance (see Schifano 2018), we see that the subject and object in old Venetian are able to vacate the VP and raise to T (see Ledgeway 2021 for similar findings for old French). Arguably, this could be representative of the incipient development of the EPP feature on $\mathrm{T}$ that characterises verb and subject movement in modern Romance. All in all, this would be further proof of the loss of the V2 constraint and a move towards the fixed SVO orders and lack of V-to-C raising that characterises declaratives in modern Venetian.

\section{Conclusion}

This paper has documented and analysed the extensive data corroborating the presence of a verb second constraint in $14^{\text {th }}$ century old Venetian. It has been proposed that the text under examination in this paper represents a stage of later old Venetian in which, whilst the V2 constraint still holds and is exemplified by: the general $\mathrm{V}$-to-C raising of the finite verb in matrix contexts, enclisis of clitics in V1 orders, and ben fronting, we observe that this constraint is nonetheless restricted, following on from recent proposals for the later stages of old northern Romance (Ledgeway 2020, 2021; Wolfe 2020; 2021). Namely, it has been proposed that the V2 constraint was being lost at this stage of later old Venetian documented through: the infrequency of Information Fronting in CP, whereby rhematic objects, are most felicitously licensed post-verbally, the low number of scrambling structures, the argued incipient cliticisation of subject pronouns, and the V-to-T movement found in embedded clauses. Arguably, this is indicative of the development of the non-V2 SVO order that characterises declarative clauses in modern Venetian. This data highlighting the restricted nature of the V2 constraint in later old Venetian have been shown to have parallels not only in other later old Venetian texts (Benincà 1984, Wolfe 2018), but parallels in other 
old northern Romance varieties and old English. All in all, the findings of this paper add to a growing scholarship that identifies the later medieval stages of the V2 constraint in northern Romània as being more restricted and bridges a gap between the this stage of old Venetian and the word orders that we find in modern Venet(i)an varieties.

\section{References}

Adams, Marianne. 1987. Old French, null subjects, and verb second phenomena. $\mathrm{PhD}$ thesis. UCLA.

Alexiadou, A. \& T. Lohndal. 2018. V3 in Germanic: a comparison of urban vernaculars and heritage languages. Linguistische Berichte Sonderheft 25: 245-264.

Batllorí, Monserrat \& María Lluïsa Hernanz. 2015. Weak focus and polarity: Asymmetries between Spanish and Catalan. In: Biberauer, T.; Walkden, G. (eds.), Syntax over Time: Lexical, Morphological and InformationStructural Interactions. Oxford: Oxford University Press. https://doi.org/10.1093/acprof:oso/9780199687923.003.0017

Belletti, Adriana. 2004. Aspects of the low IP area. In L. Rizzi (ed.), The Structure of CP and IP. Oxford: Oxford University Press.

Belletti, Adriana \& Ur Shlonsky. 1995. The order of verbal complements: a comparative study. In Natural Language and Linguistic Theory 13, 489526.

https://doi.org/10.1007/bf00992739

Benincà, Paola. 1983. Un'ipotesi sulla sintassi delle lingue romanze medievali. Quaderni patavine di linguistica 4: 3-19.

Benincà, Paola. 1995. Complement clitics in medieval Romance: The ToblerMussafia law. In I. Roberts \& A. Battye (eds.), Clause structure and linguistic change, 325-344. Oxford: Oxford University Press.

Benincà, Paola. 2004. The Left Periphery of Medieval Romance. Studi Linguistici e Filologici Online 2: 243-297.

Benincà, Paola. 2006. A detailed map of the left periphery in medieval Romance. In R. Zanuttini (ed.), Crosslinguistic research in syntax and semantics: Negation, tense and clausal architecture, 53-86. Georgetown: Georgetown University Press. https://doi.org/10.1093/fmls/cq1134

Benincà, Paola \& John Haiman. 1992. The Rhaeto-Romance Languages. London: Routledge. https://doi.org/10.4324/9780203992487

Benincà, Paola \& Cecilia Poletto. 2004. Topic, Focus, and V2: Defining the CP sublayers. In Rizzi (ed.), The structure of $C P$ and IP: The cartography of syntactic structures, vol. 2, 52-75. Oxford: Oxford University Press.

Benincà, Paola, Mair Parry, and Diego Pescarini. 2016. The Dialects of Northern Italy. In A. Ledgeway and M. Maiden (ed.), The Oxford Guide to the romance Languages, 198-205. Oxford: Oxford University Press. https://doi.org/10.1093/acprof:oso/9780199677108.003.0013

Casalicchio, Jan \& Federica Cognola. 2018. Verb-Second and (micro)-variation in two Rhaeto-Romance varieties of Northern Italy. In R. D'Alessandro \& D. Pescarini (eds.), Advances in Romance Dialectology, 72-106. Leiden: Brill. 
https://doi.org/10.1163/9789004354395_005

Casalicchio, Jan \& Federica Cognola. 2020. Parametrising 'lexical subject-finite verb' inversion across V2 languages. On the role of Relativised Minimality at the vP edge. In S. Wolfe \& R. Woods (eds). Rethinking Verb Second, 594-622. Oxford/New York: Oxford University Press.

https://doi.org/10.1093/oso/9780198844303.003.0025

Cinque, Guglielmo. 1999. Adverbs and Functional Heads. Oxford/New York: Oxford University Press.

Cognola, Federica \& Norma Schifano. 2018. On ben in Trentino regional Italian. In J. Berns, H. Jacobs, \& D. Nouveau (eds.), Romance Languages and Linguistic Theory 13: selected papers from 'Going Romance' 29, Nijmegen, 55-73. Amsterdam: John Benjamin. https://doi.org/10.1075/rllt.13.05 cog

Cruschina, Silvio. (2006). Informational focus in Sicilian and the left periphery. In F. Frascarelli (ed.), Phases of Interpretation, 363-385. Berlin: Mouton. https://doi.org/10.1515/9783110197723.5.363

Cruschina, Silvio \& Eva-Maria Remberger. 2009. Focus fronting in Sardinian and Sicilian. In V. Moscati \& E Servidio (eds.), Proceedings XXXV Incontro di Grammatica Generativa, 118-130. Siena: Università degli Studi di Siena.

den Besten, Hans. 1977. On the interaction of root transformations and lexical deletive rules. In W. Abraham (ed.), On the Formal Syntax of the Westgermania, 47-131. Amsterdam: John Benjamins. https://doi.org/10.1075/la.3.03bes

Fiéis, Alexandra. 2003. Ordem de Palavras, Transitividade e Inacusatividade. Reflexão Teórica e Análise do Português dos Séculos XIII a XVI. Phd thesis. Nova University Lisbon.

Fontana. Josep. M. 1993. Phrase structure and the syntax of clitics in the history of Spanish. Ph.D. thesis. University of Pennsylvania.

Fontana. Josep. M. 1997. On the integration of second position phenomena. In A. van Kemenade \& N. Vincent (eds.), Parameters of morphosyntactic change, 207-249. Cambridge: Cambridge University Press.

Franco, Irene. 2009. Verbs, Subjects and Stylistic Fronting. A comparative analysis of the interaction of CP properties with verb movement and subject positions in Icelandic and old Italian. PhD Dissertation, University of Siena.

Franco, Irene. 2014. The main/embedded asymmetry in Old Italian Stylistic Fronting. Presented at LSRL 44.

Grignani, Maria Antonietta \& Carla Sanfilippo. 1975. La navigazione di San Brandano. Milan: Bompiani.

Grewendorf, Günther. 2005. The discourse configurationality of scrambling. In: J. Sabel \& M.Saito (eds.), The Free Word Order Phenomenon: Its Syntactic Sources and Diversity, 75-135. Berlin: Mouton de Gruyter [Studies in Generative Grammar 69]. https://doi.org/10.1017/s0022226706264582

Haeberli, Eric. 1999. On the word order 'XP-subject' in the Germanic languages. Journal of Comparative Germanic Linguistics 3. 1-36.

Haeberli, Eric. 2000. Adjuncts and the syntax of subjects in Old and Middle English. In Pintzuk et al. (eds.). 109-131.

Holmberg, Anders. 2015. Verb second. In In: T. Kiss \& A. Alexiadou (eds.), Syntax - an International Handbook of Contemporary Syntactic Research, 342-382. Berlin: Walter de Gruyter Verlag, 2013. 
Jayaseelan, Karattuparambil Achuthan. 2001. IP-internal Topic and Focus phrases. In Studia Linguistica 55.1, 39- 75.

Jones, Michael A. 1993. Sardinian Syntax. London/New York: Routledge. https://doi.org/10.1111/1467-9582.00074

Kaiser, Georg A. 2002. Verbstellung und Verbstellungswandel in den romanischen Sprachen. Berlin, Boston: De Gruyter. https://doi.org/10.1515/9783110911640

Koopman, Willem F. 1998. Inversion after single and multiple topics in Old English. In Fisiak, J. and M. Krygier (ed.) Advances in English historical linguistics. Berlin: Mouton de Gruyter. 135-149. https://doi.org/10.1515/9783110804072.135

Lambrecht, Knud. 1994. Information structure and sentence form: Topic, focus and the mental representations of discourse referents. Cambridge: Cambridge University Press. https://doi.org/10.1017/cbo9780511620607

Ledgeway, Adam. 2007. Old Neapolitan word order: some initial observations'. In A. L. Lepschy \& A. Tosi. (eds.), Histories and dictionaries of the languages of Italy, 121-149. Ravenna: Longo.

Ledgeway, Adam. 2008. Satisfying V2 in early Romance: Merge vs. Move. Journal of Linguistics 44 (02): 437-470. https://doi.org/10.1017/s0022226708005173

Ledgeway, Adam. 2009. Grammatica diacronica del napoletano. (Beihefte zur Zeitschrift für romanische Philologie Band 350). Tübingen: Max Niemeyer Verlag, xxiv + 1045 pp. https://doi.org/10.1515/9783484971288

Ledgeway, Adam. 2010. Introduction: The clausal domain: CP structure and the left periphery. In R. D'Alessandro, A. Ledgeway, \& I. Roberts (eds), Syntactic variation: The dialects of Italy, 38-52. Cambridge: Cambridge University Press. https://doi.org/10.1515/zrp-2013-0134

Ledgeway, Adam. 2020. The North-South Divide: Parameters of Variation in the Clausal Domain. L'Italia Dialettale 81:29-77.

Ledgeway, Adam, 2021. 'V2 Beyond Borders: The Histoire Ancienne jusqu'a César', in C. Meklenborg and S. Wolfe (eds), Secrets of Success, special issue of Journal of Historical Syntax 5(29):1-65. https://doi.org/10.18148/hs/2021.v5i29.83

Lightfoot, David. 1993. Why UG needs a learning theory: Triggering verb movement. In C. Jones (ed.), Historical linguistics: Problems and perspectives, 190-214. London: Longman.

Lightfoot, David. 1995. Why UG needs a learning theory: Triggering verb movement. In A. Battye \& I. Roberts (eds), Clause structure and language change. 31-52. Oxford: Oxford University Press.

Lightfoot, David. 1997. Castastrophic change and learning theory. In Lingua 100. 171-92.

Lightfoot, David. 1999. The development of language: Acquisition, change, and evolution. Wiley-Blackwell.

Sainzmaza-Lecanda, Lorena. 2016. Preverbal information focus in Basque spanish: Evidence from Basque-Spanish bilinguals. Presented at Bilingualism Forum 2016, Ohio State University. 
Marchello-Nizia, Christiane. 1999. Le français en diachronie: douze siècles d'évolution. Paris: Ophrys. https://doi.org/10.1484/j.rph.2.304480

Martins, Ana Maria. 2001. Documentos Portugueses do Noroeste e da Região de Lisboa. Da Produção Primitiva ao Século XVI. Lisboa: Imprensa Nacional - Casa da Moeda. https://doi.org/10.14195/2183-1718_67_10

Martins, Ana Maria. 2002. The Loss of IP-scrambling in Portuguese: Clause structure, word order variation and change. In: Lightfoot, David W. (ed.). Syntactic Effects of Morphological Change, 232-248. Oxford/New York: Oxford University Press. https://doi.org/10.1093/acprof:oso/9780199250691.003.0013

Martins, Ana Maria. 2011. Scrambling and Information Focus in Old and Contemporary Portuguese. In Catalan Journal of Linguistics, 10: 133-158. https://doi.org/10.5565/rev/catj1.35

Manzini, M. Rita \& Leonardo M. Savoia. 2005. I dialetti italiani e romanci: Morfosintassi generativa. Alessandria: Edizioni dell'Orso.

Mussafia, Alfredo. 1888. Enclisi o proclisi del pronome personale atono quale oggetto. In Romania 27, 145-146.

Nicolae, Alexandru. 2015. Ordinea constituenților în limba română: $O$ perspectivă diacronică. Structura propoziției şi deplasarea verbului. Bucharest: Editura Universității din București.

Nicolae, Alexandru. 2019. Word Order and Parameter Change in Romanian. A Comparative Romance Perspective. Oxford: Oxford University Press. https://doi.org/10.1093/oso/9780198807360.001.0001

Pescarini, Diego. 2016. Clitic pronominal systems: Morphophonology. In A. Ledgeway and M. Maiden (ed.), The Oxford Guide to the Romance Languages, 742-758. Oxford: Oxford University Press. https://doi.org/10.1093/acprof:oso/9780199677108.003.0045

Perlmutter, David M. 1978. Impersonal passives and the Unaccusative Hypothesis" . Proc. of the 4th Annual Meeting of the Berkeley Linguistics Society, 157-189. UC Berkeley. https://doi.org/10.3765/bls.v4i0.2198

Poletto, Cecilia. 2006. Old Italian Scrambling: The Low Left Periphery of the Clause. In P. T. Brandt \& E. Fuss (eds.), Form, Structure, and Grammar: A Festschrift Presented to Günther Grewendorf on Occasion of His 60th Birthday, 209-229. Berlin: Akademie Verlag. https://doi.org/10.1524/9783050085555.209

Poletto, Cecilia. 2014. Word order in old Italian. Oxford: Oxford University Press.

Remberger, Eva-Maria. 2010. Left peripheral interactions in Sardinian. In K. K. Grohmann and I.M. Tsimpli (eds.) Lingua 118, [Special Issue: Exploring the Left Periphery]. https://doi.org/10.1016/j.lingua.2008.10.010

Ribeiro, Ilza. 1995. Evidence for a verb-second phase in Old Portuguese. In A. Battye \& I. Roberts (eds.), Clause structure and language change, 110-139. Oxford: Oxford University Press.

Richards, Marc D. 2004. Object Shift and Scrambling in North and West Germanic: A Case Study in Symmetrical Syntax. PhD dissertation. Univerity of Cambridge. 
Rinke, Esther. 2007. Syntaktische Variation aus aynchronischer und diachronischer Perspektive. 1., Aufl. Vervuert Verlagsges. https://doi.org/10.31819/9783964561930

Rinke, Esther \& Ioanna Sitaridou. 2004. Word order in Old Romance: a comparative study of Old French, Old Portuguese and Old Occitan', Deutsche Gesellschaft für Sprachwissenschaft (DGfS), University of Mainz, 25-27/2/2004. https://doi.org/10.1515/flin.2012.019

Rizzi, Luigi. 1997. The fine structure of the left periphery. In L. Haegeman (ed.), Elements of grammar: Handbook of generative grammar, 281-338. Dordrecht: Kluwer. https://doi.org/10.1007/978-94-011-5420-8_7

Roberts, Ian. 1993. Verbs and diachronic syntax: a comparative history of English and French. Dordrecht: Kluwer.

Rodríguez Molina, Javier. 2010. La gramaticalización de los tiempos compuestos en español antiguo: Cinco cambios diacrónicos. Phd dissertation, Universidad Autónoma de Madrid.

Ross, John. 1967. Constraints on variables in Syntax. PhD. Dissertation. Cambridge, Mass.: MIT.

Schifano, Norma \& Federica Cognola. 2020. From macro to nano: a Parametric Hierarchy Approach to the diatopic and diachronic variation of Italian ben. In T. Biberauer, J. Douglas, A. Bárány and S. Vikner (eds.), Clausal Architecture and Its Consequences: Synchronic and Diachronic Perspectives (Vol 1), 233-251. Language Science Press.

Sitaridou, Ioanna. 2011. Word Order and Information Structure in Old Spanish. Catalan Journal of Linguistics, Special Issue on 'Word Order and Information Structure': 159-184. https://doi.org/10.5565/rev/catj1.36

Sitaridou, Ioanna. 2012. A Comparative Study of Word Order in Old Romance. Folia Linguistica 46/2 'The Pace of Grammaticalisation in Romance': 553604. https://doi.org/10.1515/flin.2012.019

Tagliani, Roberto. 2014. «Navigatio Sancti Brendani»: volgarizzamento veneziano del ms. Paris, BnF, it. 1708. Carte Romanze. 2: 9-124.

Tobler, Adolf. 1875. Besprechung von J. Le Coultre, De l'ordre des mots dans Chrétien de Troyes. Vermischte Beiträge zur französischen Grammatik 5, 395-414.

Urrutia-Cárdenas, Hernán. (1988). El español en el País Vasco: Peculiaridades morfosintácticas. Letras de Deusto, 40, 33-46.

Vance, Barbara. 1997. Syntactic change in medieval French: Verb-second and null subjects. Dordrecht: Kluwer. https://doi.org/10.1075/dia.16.2.15sch

Vanelli, Laura. 1986. Strutture tematiche in italiano antico, In H. Stammerjohann (ed.), Tema-Rema in Italiano, 249-273. Tübingen, Gunter Narr Verlag.

Vanelli, Laura. 1997. Personal pronouns and demonstratives. In M. Maiden \& M. Parry (eds.), The Dialects of Italy, 106-116. London \& New York: Routledge.

Vanelli, Laura, 1998, Ordine delle parole e articolazione pragmatica dell'italiano antico: la "prominenza" pragmatica della prima posizione nella frase. Medioevo Romanzo 23(2): 229-246. 
Vanelli, Laura, Luigi Rizzi \& Paola Benincà. (1985). Typologie des pronoms sujets dans les langues romanes. In P. Benincà (ed.), La variazione sintattica, 195-211. Bologna: Il Mulino.

Van Kemenade, Ans. 1987. Syntactic case and morphological case in the history of English, Berlin: Mouton de Gruyter.

Vikner, Sten. 1994. Scandinavian Object Shift and West Germanic Scrambling. In N. Corver \& H. van Riemdijk (eds.), Studies in Scrambling: Movement and Non- Movement Approaches to Free Word-Order Phenomena, 487-517. Berlin: de Gruyter. https://doi.org/10.1515/9783110857214.487

Walkden, George. 2017. Language contact and V3 in Germanic varieties new and old. Journal of Comparative Germanic Linguistics 20(1): 49-81. https://doi.org/10.1007/s10828-017-9084-2

Weise, Heike. 2009. Grammatical innovation in multiethnic urban Europe: new linguistic practices among adolescents. Lingua 119: 782-806. https://doi.org/10.1016/j.lingua.2008.11.002

Wolfe, Sam. 2015, Microvariation in Old Italo-Romance Syntax: The View from Old Sardinian and Old Sicilian. In Archivio Glottologico Italiano 100(1): 336.

Wolfe, Sam. 2016. A Comparative Perspective on the Evolution of Romance Clausal Structure. In Diachronica 33:4: 461-502. https://doi.org/10.1075/dia.33.4.02wol.

Wolfe, Sam. 2017. Syntactic Variation in Two Sister Languages:A Study of Word Order in Old French and Old Occitan. In R. Zafiu, G. Dindelegan, A. Dragomirescu, \& A. Nicolae (eds.), Romance Syntax. Comparative and diachronic perspectives, 53-85. Newcastle: Cambridge Scholars.

Wolfe, Sam. 2018. Verb Second in Medieval Romance. Oxford, Oxford University Press. https://doi.org/10.1093/oso/9780198804673.001.0001

Wolfe, Sam. 2020. Rethinking Medieval Romance Verb Second. In R. Woods and S. Wolfe (eds.), Rethinking Verb Second. Oxford: Oxford University Press. https://doi.org/10.1093/oso/9780198844303.001.0001

Wolfe, Sam. 2021. Back to the Future. The Romance North/South divide in synchrony and diachrony, paper presented at the Residual Verb Second in Romance 'Through the looking glass' workshop, University of Helsinki. (10 June 2021).

Yang, Charles. 2000. Knowledge and learning in natural language. $\mathrm{PhD}$ dissertation. Massachusetts Institute of Technology. 